\title{
Analisis Yuridis Mengenai Kedudukan Kode Etik Bankir Dalam Dimensi Tindak Pidana Perbankan
}

\author{
Hatta Zul ${ }^{1 *}$, Erwin Yulianto ${ }^{2}$ \\ ${ }^{1}$ Magister Ilmu Hukum, Fakultas Hukum, Universitas Parahyangan, Bandung, Indonesia \\ ${ }^{2}$ Teknik Informatika, Fakultas Teknik, Universitas Langlangbuana, Bandung, Indonesia \\ *Correspondence email: hatta@gmail.com, rwinyulianto@yahoo.com
}

\begin{abstract}
Abstrak. Tujuan penelitian ini, untuk merumuskan pengimplementasian kode etik bankir dalam menjalankan profesi pegawai perbankan dapat meminimalisir terjadinya tindak pidana perbankan. Metode yang digunakan dalam penelitian adalah yuridis normatif, dengan spesifikasi deskriptif analitis, melalui studi kepustakaan dan studi lapangan, kemudian dianalisis secara kualitatif non-matematis. Kesimpulan dengan adanya Kode Etik Bankir, seorang bankir diharapkan dapat menjalankan tugasnya tanpa melanggar ketentuan - ketentuan yang ada sehingga dapat menghindari adanya tindakan-tindakan (terutama tindak pidana) yang dapat merugikan nasabah.
\end{abstract}

Kata kunci: Hukum Perbankan; Kode Etik Bankir; dan tindak pidana.

Abstract. The purpose of this research is to formulate the implementation of a banker code of ethics in carrying out the banking employee profession to minimize the occurrence of banking crimes. The method used in this research is normative juridical, with descriptive analytical specifications, through literature study and field studies, then analyzed qualitatively non-mathematically. Conclusion with the existence of the Banker Code of Ethics, a banker is expected to be able to carry out his duties without violating existing provisions so as to avoid actions (especially criminal acts) that can harm customers.

Keywords: Banking Law; Banker Code of Ethics; and Criminal Acts.

\section{PENDAHULUAN}

Keinginan untuk menempatkan etika yang berjalan seiring dengan hukum adalah idealitas dalam kehidupan bermasyarakat. Keduanya berbeda ranah, tetapi tidak saling terpisah. Meski dimungkinkan untuk ada pembatasan, tetapi diantara keduanya saling membangun keterhubungan. Hubungan tersebut sangat tergantung dari sudut pandang atau perspektif yang digunakan khususnya terhadap hukum.

K. Bertens mengemukakan bahwa etika adalah nilai dan norma moral yang menjadi pegangan bagi seseorang atau suatu kelompok dalam mengatur tingkah lakunya, kumpulan asas atau nilai moral, dan ilmu tentang baik dan buruk. Etika berada di luar hukum, namun sekaligus menjadi inspirasi bagi pembentukan hukum. Sehingga menempatkan etika sebagai hukum tergantung pada sudut pandang hukum yang digunakan. ${ }^{1}$

Memperhatikan definisi hukum yang menyatakan bahwa hukum itu dapat berupa hukum tertulis dan hukum tidak tertulis, apabila hukum didefinisikan sebagai perintah, larangan, dan sanksi yang dibuat oleh kekuasaan yang memiliki legitimasi, maka etika tidak termasuk dalam (pengertian) hukum tersebut. Berbeda halnya apabila memperhatikan definisi terakhir, etika dapat dikategorikan sebagai hukum tidak tertulis.

Etika dan hukum dapat dikotomikan, tetapi sulit untuk dipisahkan. Bahkan secara tendensius dapat dikemukakan bahwa hukum (peraturan perundang-

${ }^{1}$ K Bertens, Etika, Gramedia, Jakarta, 1993, hlm. 27. undangan) dapat dibentuk tanpa etika, tetapi etika agar mempunyai keberlakuan yang lebih mengikat harus dipositivisasi. Peraturan perundang-undangan tanpa etika akan memicu perdebatan, yaitu dalam hal pembentukannya mengabaikan nilai-nilai universal yang dianut dalam masyarakat. Yang dianut pada pembentukan hukum tanpa etika adalah keinginan pemegang kekuasaan yang mengutamakan nilai-nilai individual yang diyakini. Dengan demikian cukup mustahil hukum dapat dibentuk tanpa etika, karena terkait baik dan buruk yang menjadi pedoman berperilaku sudah menjadi prinsip kajian etika. ${ }^{2}$

Etika menjadi supporting system atau sistem pendukung dari hukum, meski tidak harus menjadi backbone dari hukum. Namun demikian keberadaan etika mampu memberikan arahan dan 'cita rasa' hukum yang dikehendaki. Pemahaman mengenai etika akan memberi pengaruh pada hukum yang akan atau bahkan pada hukum yang sudah terbentuk. Sehingga dari hukum dapat diketahui jejak-jejak nilai yang ditransformasikan. Hukum tanpa etika adalah kemustahilan, etika tanpa hukum memiliki keterbatasan daya jangkaunya. Sehingga meskipun berbeda saling melengkapi diantara keduanya dalam menata dan memedomani interaksi sosial kemasyarakatan.

2 Yakob Adi Krisanto, "Hukum Vs. Etika atau Hukum=Etika?,"

https://www.kompasiana.com/yakubadi/5500d3f4a333115372 512375/hukum-vs-etika-atau-hukum-etika, dikases 18 Oktober 2020, pukul 00.31 WIB. 
Dalam kaitannya dalam kehidupan bermasyarakat, perbankan memiliki peran strategis dalam kegiatan pembangunan khususnya di dalam sistem perekonomian dan keuangan nasional. Sebagaimana diamanatkan di dalam Pasal 3 Undang-Undang Nomor 7 Tahun 1992 tentang Perbankan jo. Undang-Undang Nomor 10 Tahun 1998 tentang Perubahan Undang-Undang Nomor 7 Tahun 1992 tentang Perbankan, fungsi utama perbankan adalah sebagai lembaga intermediasi, yaitu lembaga yang menghubungkan masyarakat yang mengalami kelebihan dana (surplus of fund) dengan masyarakat yang mengalami kekurangan dana (lack of fund).

Fungsi strategis dari sektor perbankan tersebut sesuai dengan Pasal 4 Undang-Undang No. 7 Tahun 1992 jo. Undang-undang Nomor 10 Tahun 1998 tentang Perubahan Undang-Undang Nomor 7 Tahun 1992 Tentang Perbankan selanjutnya disingkat UU Perbankan, menyatakan bahwa perbankan di Indonesia bertujuan menunjang pelaksanaan pembangunan nasional dalam rangka meningkatkan pemerataan pertumbuhan ekonomi dan stabilitas nasional ke arah peningkatkan kesejahteraan rakyat banyak.

Untuk mencapai kejelasan objek penelitian dan kejelasan permasalahan, peneliti akan menganalisis kedudukan profesi bankir sebelumnya. Bankir menurut Kamus Besar Bahasa Indonesia (KBBI) adalah orang yang mengusahakan bank; orang yang memperdagangkan uang; orang yang menjadi penyokong dalam urusan keuangan; dan cukong. ${ }^{3}$

Menurut Ranuhandoko pengertian dari "bankir atau banker adalah orang yang menjabat sebagai pemimpin dan atau ahli dalam perbankan." ${ }^{4}$ Sedangkan dalam Black Law Dictionary pengertian dari Bankir atau banker adalah " a person who engages in bussines of banking." Peneliti menerjemahkan secara bebas sebagai seseorang yang berprofesi secara khusus dalam dunia perbankan.

Untuk meningkatkan profesionalitas, maka seorang berprofesi sebagai bankir mampu menjalankan tugasnya tanpa melanggar kode etik profesi. Kode etik profesi bankir haruslah membahas tentang kewajiban dan keharusan untuk menjalankan profesinya secara tanggung jawab atas perbuatan tanpa melanggar hukum pidana. Hubungan keduanya sangat erat, dimana adanya kode etik didalam profesi perbankan maka masyarakat akan merasa adanya jaminan kepercayaan pada institusi perbankan.

Bankir pada dasarnya bukanlah suatu profesi mandiri, tetapi profesi yang bekerja pada suatu perusahaan berbadan hukum. Sehingga dalam

3 Kemendikbud, Kamus Besar Bahasa Indonesia (KBBI), Jakarta, 2020, hlm. 52.

4 I.P.M. Ranuhandoko, Terminologi Hukum, Sinar Grafika, Bandung, 2006, hlm. 86.

5 Bryan. A. Garner, Black's Law Dictionary, West Publishing CO, U.S., 1999, hlm. 155 pelaksanaanya pelanggaran kode etik, tidak seperti profesi mandiri lainnya (dokter, akuntan publik, notaris, dll.) yang melindungi anggota dari tuntutan pidana, sebelum adanya sidang kode etik. Pelanggaran kode etik yang dilakukan pegawai akan diberikan sanksi oleh perusahaan, sedangkan pelanggaran kode etik yang dilakukan secara sistematik oleh perusahaan akan diberikan sanksi oleh Bank Indonesia. Sehingga pelanggaran kode etik bankir yang menyebabkan kerugian pada nasabah, perusahaan perbankan, ekonomi nasional, dan kerugian Bank Sentral, bukan menjadi tanggung jawab IBI, tetapi dapat berujung dengan pidana. Sebagaimana diatur di dalam Pasal 46 - 53 UU Perbankan, mengenai larangan yang dapat menyebabkan bankir diancam hukuman pidana.

Setiap pelanggaran hukum perbankan, akan menjadi pelanggaran kode etik perbankan, karena di dalam Huruf a Kode Etik Bankir, ditegaskan bahwa:

"Seorang bankir patuh dan taat pada ketentuan perundangan dan peraturan yang berlaku."

Dengan adanya kode etik yang menjadikan ketidakpatuhan merupakan pelanggaran, maka setiap pelanggaran hukum merupakan pelanggaran kode etik. Akan tetapi, pelanggaran Kode Etik Bankir tidak akan menjadi pelanggaran hukum. Serta pelanggaran kode etik tidak akan memiliki sanksi hukum. Sanksi yang disepakati ikatan profesi, berupa sanksi administrasi, Surat Peringatan, dan teguran.

Kode etik bankir sebagai pedoman dasar bankir dalam melaksanakan profesinya di bidang perbankan. Kode etik bankir merupakan suatu norma dasar yang menjadi acuan perilaku pegawai perbankan, jika norma ini dipegang teguh tentunya tidak akan terjadi tindak pidana perbankan. Perbankan dalam keungan negara saat ini memiliki peran yang vital dengan bangkrutnya suatu bank, dapat menimbulkan kerugian pada negara.

Kode Etik yang dijalankan akan berefek dengan individu yang berintegritas. Tetapi untuk tindak pidana, pertanggungjawaban pidana karenanya menyangkut proses peralihan hukuman yang ada pada tindak pidana kepada pembuatnya. Mempertanggungjawabkan seseorang dalam hukum pidana adalah meneruskan hukuman yang secara objektif ada pada perbuatan pidana secara subjektif terhadap pembuatnya. Pertanggungjawaban pidana ditentukan berdasarkan pada kesalahan pembuat dan bukan hanya dengan dipenuhinya seluruh unsur tindak pidana. Pertanggungjawaban pidana adalah mengenakan hukuman terhadap pembuat karena perbuatan yang melanggar larangan atau menimbulkan keadaan yang terlarang. Dengan demikian kesalahan ditempatkan sebagai faktor penentu pertanggungjawaban pidana dan 
tak hanya dipandang sekedar unsur mental dalam tindak pidana. ${ }^{6}$

Atas permasalahan tidak patuhnya, tidak mengerti, dan tidak tertanam di sanubari karyawan perbankan, yaitu Kode Etik. Maka tindak pidana yang merugikan bank, merugikan negara, merugikan profesi, dan menyebabkan muncul konsekuensi hukum terhadap pelaku, seharusnya dapat dihindarkan. perbankan lebih senang terhadap karyawan yang dapat memberikan keutungan sesaat, tetapi kode etik tidak menjadi suatu persoalan yang mendasar.

\section{METODE}

Penelitian ini menggunakan metode yuridis normatif, yaitu penelitian kepustakaan terhadap data sekunder di bidang hukum perbankan yang terdiri dari bahan-bahan hukum primer dan bahan-bahan hukum sekunder. Teknik pengumpulan data yang digunakan yaitu, studi kepustakaan yang terdiri dari pencarian konsepsi-konsepsi, teori-terori, yang berhubungan dengan permasalahan perbankan berupa peraturan perundang-undangan dibidang perbankan. Spesifikasi penelitian yang digunakan bersifat deskriptif analitis dalam rangka mengkaji bahan-bahan yang bersumber dari kepustakaan dan peraturan perundang-undangan. Metode analisis data yang digunakan adalah normatif kualitatif untuk menentukan isi atau makna aturan hukum yang dijadikan rujukan dalam menyelesaikan permasalahan hukum perbankan yang dikaji.

\section{HASIL DAN PEMBAHASAN \\ Kedudukan Kode Etik Bankir Dalam Dimensi Tindak Pidana Perbankan}

Kode etik merupakan sistem norma yang tertulis melekat pada profesi tertentu. Kode etik dibuat sebagai garis besar pelaksanaan suatu profesi yang sifatnya luas. Kode etik dari segi isi biasanya mengatur sikap dan perilaku yang secara moral tertanam di sanubari orang tersebut. kode etik tidak mengatur secara detil pelaksanaan dalam menjalankan suatu profesi. Misalnya kode etik bankir Nomor 1 yang menegaskan: "Seorang bankir patuh dan taat pada ketentuan perundangan dan peraturan yang berlaku."

Ketaatan peraturan perundang-undangan yang berlaku tentunya luas, tidak spesifik mengatur perundang-undangan yang perlu diketahui dan dilaksanakan bankir. Kode etik perbankan menginginkan adanya norma perilaku yang berprofesi sebagai bankir taat pada keseluruhan peraturan perundang-undangan yang ada, dengan kata lain bankir haruslah taat hukum.

Peraturan perundnag-undangan yang ada dan harus ditaati sesuai dengan asas presumption iures de iure bahwasanya semua peraturan perundang-undangan

${ }^{6}$ Chairul Huda, Dari Tiada Pidana Tanpa Kesalahan Menuju Kepada Tiada Pertanggungjawaban Pidana Tanpa Kesalahan, Kencana Prenada Media, Jakarta, 2006, hlm. 4. yang diundangkan dianggap diketahui dan harus dipatuhi. Pelanggaran hukum yang tidak diketahui sebelumnya dianggap bukan alasan. Bahwasanya setiap orang dewasa yang cakap hukum harus mencari tahu perundang-undangan yang disahkan oleh penguasa.

Tindak pidana menurut peneliti sebagai tindakan seseorang yang mengganggu ketertiban umum dan tindakan tersebut diatur dalam peraturan perundangundangan, serta adanya sanksi yang tegas bagi pelanggarnya. Adanya tindak pidana pada kejahatan perbankan menjadi objek kajian peneliti agar tindak pidana tersebut dapat terminimalisir. Keberadaan kode etik bankir dirasa dapat meminimalisir hal tersebut dan juga melindungi profesional perbankan dalam tindakannya, untuk tidak serta merta mengklasifikasikan perbuatan tersebut menjadi tindak pidana.

Hubungan antara etika dengan hukum bisa dilihat dari 3 (tiga) dimensi yakni dimensi substansi dan wadah, dimensi hubungan keluasan cakupannya serta dimensi alasan manusia untuk mematuhi atau melanggarnya. Ketiga dimensi ini menurut pendapat beberapa ahli hukum yang memiliki perhatian khusus terhadap etik. ${ }^{7}$

Jimly Asshiddiqie, mengibaratkan hubungan antara hukum dengan etika dengan memberi catatan agama sebagai ruh atau jiwa dari kedua hal tersebut dengan ilustrasi nasi bungkus, hukum sebagai bungkusnya, nasi beserta lauknya adalah etikanya, dan zat protein, vitamin, dan unsur-unsur terkandung lainnya sebagai agama yang merupakan asal-usul dari keduanya (etika dan hukum). Dimensi ketiga cakupan luasan atas hubungan etik dan hukum dimana etika lebih luas dari hukum, karena itu setiap pelanggaran hukum pasti merupakan pelanggaran etik, singkat kata pelanggaran hukum adalah pelanggaran etik. Namun tidak demikian sebaliknya, pebuatan yang dianggap meanggar etik belum tentu melanggar hukum. Jika etika diibaratkan sebagai samudera maka kapalnya adalah hukum sebagaimana ditegaskan Ketua Mahkamah Agung Earl Warren "Law floats in the sea of ethics."

Paulus Harsono mensitir tentang dimensi ketiga ini, terkait kedudukan etika dimana etika juga berhubungan dengan hukum dalam hal bagaimana manusia mempertimbangkan untuk mematuhi peraturan dan kewajiban, tetapi dipatuhinya hukum serta peraturan dan kewajiban itu bukan karena takut akan dikenai sanksi, tetapi karena kesadaran diri bahwa hukum serta peraturan dan kewajiban tersebut baik dan perlu dipenuhi oleh dirinya sendiri. Masih relevan dengan pandangan Paulus Harsono, dalam hal perilaku manusia, etika berfungsi sebagai pagar preventif atas perilaku baik

${ }^{7}$ Sri Pujiningsih, "Hubungan Antara Hukum dan Etika dalam Politik Hukum di Indonesia (Membaca Pancasila sebagai Sumber Nilai dan Sumber Etik)," Pena Justisia: Media Komunikasi dan Kajian Hukum Vol. 17 No. 1, 2017, hlm. 34.

8 Jimly Asshiddiqie, Peradilan Etik dan Etika Konstitusi, PT. Sinar Grafika, Jakarta, 2016, hlm. 14. 
dan buruk sebelum perilkau menjangkau ketentuan benar dan salah yang merupakan fungsi pagar perilaku bagi hukum. Dengan demikian, perilaku menyimpang manusia harus melewati sistem etika yang berfungsi sebagai koreksi dan sebisa mungkin tidak perlu memasuki mekanisme hukum dalam penyelesaian penyimpangan perilaku manusia tersebut. ${ }^{9}$

Korelasi antara kode etik bankir dengan tindak pidana perbankan menurut peneliti memiliki 2 (dua) aspek penting, yaitu:

1. Pencegahan, kode etik yang tertanam di sanubari profesional bankir dapat mencegah bankir untuk melakukan tindak pidana perbankan. Kode etik sebagai rambu-rambu awal saat manusia berfikir untuk melakukan tindakannya.

2. Landasan perilaku, profesional perbankan dalam menjalankan kegiatannya memiliki landasan dasar, yaitu kode etik bankir yang sifatnya general, mendorong manusia untuk senantiasa berbuat baik dan penuh tanggung jawab. Hal ini tentunya menjadikan bankir tidak terlibat tindak pidana.

Bankir adalah orang yang bekerja dengan status pegawai tetap atau belum tetap dengan level minimal Officer, untuk BPR level minimal satu level dibawah Direksi, secara otomatis terikat kode etik bankir. Sedangkan pegawai perbankan di bawah level tersebut, hanya terikat etika perusahaan perbankan saja. Berdasarkan hal tersebut peneliti akan menguraikan 9 (sembilan) Kode Etik Bankir dengan korelasinya terhadap tindak pidana perbankan di bawah ini:

1. Seorang bankir patuh dan taat pada ketentuan perundangan dan peraturan yang berlaku.

Kode etik bankir menanamkan asas kepatuhan dan asas taat hukum yang dibuat penguasa. Korelasi dengan norma hukum sangatlah luas, karena bankir tidak hanya dituntut untuk taat pada peraturan perbankan saja, tetapi juga norma hukum secara keseluruhan.

2. Seorang bankir melakukan pencatatan yang benar mengenai segala transaksi yang bertalian dengan kegiatan banknya.

Bankir haruslah mencatat setiap transaksi dengan benar, tersistematis, terdokumentasi, dan terlaporkan. Patuh terhadap norma ini menghindarkan dari tindak pidana pencatata palsu, sebagaimana diatur dalam Pasal 49 ayat (1) huruf a UU Perbankan, yang melarang:

"Anggota dewan komisaris, direksi atau pegawai bank yang dengan membuat atau menyebabkan adanya pencatatan palsu dalam pembukuan atau dalam laporan, maupun dalam dokumen atau

\footnotetext{
${ }^{9}$ Jimly Asshiddiqie, op.cit., hlm. 15
}

laporan kegiatan usaha, laporan transaksi atau rekening suatu bank."

3. Seorang bankir menghindarkan diri dari persaingan yang tidak sehat

Bankir dalam kedudukannya sebagai individu profesional, harus dapat bersaing secara sehat. Bankir dalam kedudukannya sebagai wakil dari badan hukum bank yang bersaing dengan bank lainnya, dihindarkan untuk melakukan kecurangan. Sesuai dengan aturan Undang-undang Nomor 5 Tahun 1999 Tentang Larangan Praktek Monopoli dan Persaingan Usaha Tidak Sehat.

4. Seorang bankir tidak meyalahgunakan wewenangnya untuk kepentingan pribadi.

Contoh kasus kejahatan perbankan berupa penyalahgunaan wewenang, yaitu kasus pembobolan uang nasabah prioritas Citibank Landmark senilai $\mathrm{Rp}$ 16,63 miliar yang dilakukan senior relationship manager (RM) bank tersebut. Inong Malinda Dee, selaku RM, menarik dana nasabah tanpa sepengetahuan pemilik melalui slip penarikan kosong yang sudah ditandatangani nasabah. Aksi yang dilakukan oleh Malinda tersebut merupakan salah satu peristiwa fraud perbankan terbesar yang pernah terjadi di Indonesia. ${ }^{10}$

Tindak pidana yang dilanggar Malinda Pasal 49 ayat (1) huruf a dan Pasal 49 ayat (2) huruf a UndangUndang Perbankan dan melanggar Pasal 3 ayat (1) huruf b Undang-Undang TPPU. ${ }^{11}$

5. Seorang bankir menghidarkan diri dari keterlibatan pengambilan keputusan dalam hal terdapat pertentangan kepentingan.

Kode etik ini tidak ada korelasi langsung dengan tindak pidana perbankan. Tetapi, mengatur bahwasannya bankir tidak boleh mengambil keputusan yang telah didalangi adanya suatu kepentingan, hal itu lebih baik dihindarkan.

6. Seorang bankir menjaga kerahasiaan nasabah dan banknya.

Korelasi kode etik yang terkait kerahasian bank telah ada aturan pidana jika tidak diindahkan oleh bankir, sebagaimana Pasal 47 ayat (2) yang melarang:

10 Sulistyandari, dosen Fakultas Hukum Univeritas Jenderal Soedirman Purwokerto, Mahasiswa S3 Ilmu Hukum Universitas Airlangga: Surabaya. Aspek Hukum Pembobolan Uang Nasabah Bank.html diterbitkan di gagasan hukum.blogspot.com tanggal 11 April 2011, diakses tanggal 15 September 2020, hlm. 1

${ }^{11}$ Herry Febrian, “Juridical Analysis On Fund Hit Of Customer Of Citibank In Perspective Of Banking Act And Act Of Eradication And Prevention Of Money Laundry," Transparency, Jurnal Hukum Ekonomi, Feb-Mei 2013 Volume I Nomor 2, hlm. 4. 
"Anggota Dewan Komisaris, Direksi, pegawai bank atau Pihak Terafiliasi lainnya yang sengaja memberikan keterangan yang wajib dirahasiakan menurut Pasal 40, diancam dengan pidana penjara sekurang-kurangnya 2 (dua) tahun serta denda sekurang-kurangnya $R p$ 4.000.000.000,00 (empat miliar rupiah) dan paling banyak $R p$ 8.000.000.000,00 (delapan miliar rupiah)."

7. Seorang bankir memperhitungkan dampak yang merugikan dari setiap kebijakan yang ditetapkan banknya terhadap keadaan ekonomi, sosial, dan lingkungan.

Bankir dalam perbuatannya harus senantiasa memperhitungkan dampak kerugian yang ditimbulkan, kerugian akibat langkah bankir yang tidak sesuai dapat menjadi sanksi pidana, sebagaimana ditegaskan dalam Pasal 50 UU Perbankan:

"Pihak Terafiliasi yang dengan sengaja tidak melaksanakan langkah-langkah yang diperlukan untuk memastikan ketaatan bank terhadap ketentuan dalam Undang-undang ini dan peraturan perundangundangan lainnya yang berlaku bagi bank, diancam dengan pidana penjara sekurang-kurang 3 (tiga) tahun dan paling lama 8 (delapan) tahun serta denda sekurang-kurangnya Rp5.000.000.000,00 (lima miliar rupiah) dan paling banyak Rp100.000.000.000,00 (seratus miliar rupiah)."

8. Seorang bankir tidak menerima hadiah atau imbalan yang memperkaya diri pribadi maupun keluarganya. Menerima imbalan bagi bankir yang dapat mempengaruhi keputusannya dapat menjadi tindak pidana. Kode etik perbankan melarang adanya bankir yang menerima hadiah atau imbalan dalam Pasal 50 ayat (2) UU Perbankan:

"Anggota Dewan Komisaris, Direksi, atau pegawai bank yang dengan sengaja:

a. meminta atau menerima, mengizinkan atau menyetujui untuk menerima suatu imbalan, komisi, uang tambahan, pelayanan, uang atau barang berharga, untuk keuntungan pribadinya atau untuk keuntungan keluarganya, dalam rangka mendapatkan atau berusaha mendapatkan bagi orang lain dalam memperoleh uang muka, bank garansi, atau fasilitas kredit dari bank, atau dalam rangka pembelian atau pendiskontoan oleh bank atas surat-surat wesel, surat promes, cek, dan kertas dagang atau bukti kewajiban lainnya, ataupun dalam rangka memberikan persetujuan bagi orang lain untuk melaksanakan penarikan dana yang melebihi batas kreditnya pada bank; b. tidak melaksanakan langkah-langkah yang diperlukan untuk memastikan ketaatan bank terhadap ketentuan dalam Undang-undang ini dan ketentuan peraturan perundang-undangan lainnya yang berlaku bagi bank, diancam dengan pidana penjara sekurang-kurangnya 3 (tiga) tahun dan paling lama 8 (delapan) tahun serta denda sekurang-kurangnya Rp5.000.000.000,00 (lima miliar rupiah) dan paling banyak Rp100.000.000.000,00 (seratus miliar rupiah)."

Untuk Bank BUMN imbalan yang dapat mempengaruhi keputusan, menguntungkan diri sendiri/orang lain, menimbulkan kerugian dalam keputusannya dapat dikategorikan sebagai perbuatan korupsi (gratifikasi). Gratifikasi termasuk tindak pidana, landasan hukumnya adalah UU 31/ 1999 dan UU 20/2001 Pasal 12:

"Penerima gratifikasi diancaman pidana penjara seumur hidup atau pidana penjara paling singkat 4 tahun dan paling lama 20 tahun dan denda paling sedikit 200 juta rupiah dan paling banyak 1 miliar rupiah."

9. Seorang bankir tidak melakukan perbuatan tercela yang dapat merugikan citra profesinya.

Pada kode etik ini bersifat luas karena memberikan landasan moral bahwasanya bankir harus berbuat baik, tidak melakukan perbuatan tercela yang dapat menurunkan martabatnya.

Immanuel Kant menjelaskan tentang hubungan antara etika dan hukum hubungan tersebut terdapat pada penyesuaian sikap, norma moral yang dihadapi adalah sikap moralitas, yaitu penyesuain diri dengan kewajiban moral. Dalam hal ini, hati nurani menjadi motivasi yang sebenarnya dari perbuatan. Tetapi pada moral hukum, yang dihadapi adalah sikap legalitas, yaitu penyesuaian diri dengan ketentuan hukum positif. ${ }^{12}$

Walaupun ada perbedaan antara norma moral dan norma hukum, antara kedua norma tersebut terdapat hubungan yang erat. Pembentukan hukum sebenarnya merupakan bagian tuntutan moral yang dialami manusia. Perintah yang mengharuskan orang untuk hidup bersama sesuai dengan prinsip-prinsip moral karenanya dibentuk undang-undang yang adil. Hukum adalah ketentuanketentuan yang menjamin kehendak pribadi, dan menurut norma hukum kebebasan. Tata hukum diartikan sebagai sikap moral manusia, karena itu hubungan yang erat dipahami karena norma moral menjadi efektif dan

12 Abdulkadir Muhammad, Etika Profesi Hukum, PT. Citra Aditya Bakti, Bandung, hlm. 17. 
dijadikan norma hukum, atau norma moral jadi sumber hukum positif. ${ }^{13}$

Korelasi kode etik perbankan dengan terminimalisirnya tindak pidana perbankan sangatlah erat, setiap tindak pidana perbankan merupakan pelanggaran kode etik. Tetapi pelanggaran kode etik belum tentu menjadi tindak pidana. Karena tindak pidana perbankan di Indonesia mengacu pada sistem Eropa Kontinental yang berasaskan legisme, bahwasannya seseorang tidak dapat dipidanakan jika belum ada aturan tertulis yang dikeluarkan penguasa. Sehingga kode etik bersifat menyentuh secara mendasar perilaku bankir untuk senantiasa berbuat baik, serta dapat terhindarkan dari tindak pidana perbankan.

\section{SIMPULAN}

Kode etik bankir berbentuk tertulis yang ditetapkan secara formal oleh organisasi profesi. Kode etik bankir bertujuan untuk menjaga martabat profesi yang bankir, dan untuk melindungi masyarakat dari penyalahgunaan keahlian dan/atau otoritas profesional. Penanaman kode etik bankir terhadap pegawai bank dapat meminimalisir terjadinya tindak pidana perbankan. Karena adanya mindset (pola pikir) bahwasanya pelayanan kepada masyarakat adalah hal utama, pengambilan keuntungan untuk diri sendiri dan golongan merupakan tindakan tidak terpuji. Serta adanya perasaan bersalah (feeling guilty) jika tidak menjalankan profesi dengan baik, hal ini tentunya menjadikan profesional perbankan menjaga martabatnya.

\section{DAFTAR PUSTAKA}

\section{Buku}

Bryan. A. Garner, 1999. Black's Law Dictionary, West Publishing CO, U.S

Chairul Huda, 2006. Dari Tiada Pidana Tanpa Kesalahan Menuju Kepada Tiada Pertanggungjawaban Pidana Tanpa Kesalahan, Jakarta: Kencana Prenada Media

I.P.M. Ranuhandoko, Terminologi Hukum, Sinar Grafika, Bandung, 2006.

Jimly Asshiddiqie, 2016. Peradilan Etik dan Etika Konstitusi, PT. Sinar Grafika, Jakarta,

Kemendikbud, 2020. Kamus Besar Bahasa Indonesia (KBBI), Jakarta

K Bertens, (1993), Etika, Gramedia, Jakarta,

\section{Jurnal}

Herry Febrian, "Juridical Analysis On Fund Hit Of Customer Of Citibank In Perspective Of Banking Act And Act Of Eradication And Prevention Of

13 Niru Anita Sinaga, "Kode Etik Sebagai Pedoman Pelaksanaan Profesi Hukum Yang Baik," Jurnal Ilmiah Hukum Dirgantara-Fakultas Hukum Universitas Dirgantara Marsekal Suryadarma | Volume 10 No. 2, Maret 2020, hlm. 3.
Money Laundry," Transparency, Jurnal Hukum Ekonomi, Feb-Mei 2013 Volume I Nomor 2.

Niru Anita Sinaga, "Kode Etik Sebagai Pedoman Pelaksanaan Profesi Hukum Yang Baik," Jurnal Ilmiah Hukum Dirgantara-Fakultas Hukum Universitas Dirgantara Marsekal Suryadarma | Volume 10 No. 2, Maret 2020.

Sri Pujiningsih, "Hubungan Antara Hukum dan Etika dalam Politik Hukum di Indonesia (Membaca Pancasila sebagai Sumber Nilai dan Sumber Etik)," Pena Justisia: Media Komunikasi dan Kajian Hukum Vol. 17 No. 1, 2017.

Sulistyandari, dosen Fakultas Hukum Univeritas Jenderal Soedirman Purwokerto, Mahasiswa S3 Ilmu Hukum Universitas Airlangga: Surabaya. Aspek Hukum Pembobolan Uang Nasabah Bank.html diterbitkan di gagasan hukum.blogspot.com tanggal 11 April 2011, diakses tanggal 15 September 2020.

Yakob Adi Krisanto, "Hukum Vs. Etika atau Hukum=Etika?,"

https://www.kompasiana.com/yakubadi/5500d3f4a 333115372512375/hukum-vs-etika-atau-hukumetika, dikases 18 Oktober 2020, pukul 00.31 WIB.

\section{Peraturan Perundang-Undangan}

Undang-Undang Republik Indonesia Nomor 10 Tahun 1998 Tentang Perubahan atas Undang-Undang Nomor 7 Tahun 1992 Tentang Perbankan.

Undang-Undang Nomor 7 Tahun 1992 tentang Perbankan

Undang-Undang Nomor 10 Tahun 1998 tentang Perubahan Undang-Undang Nomor 7 Tahun 1992 tentang Perbankan 